\title{
ADVANTAGES AND DISADVANTAGES OF PROFESSIONAL PREPARATION OF THE FUTURE FITNESS TRAINERS IN GREAT BRITAIN AND AUSTRALIA
}

\author{
Maryna Vasylenko \\ National University of Physical Education and Sport of Ukraine \\ 1A, korpus 2/192 Kurguzova str., Vyshgorod, Ukraine, 07300 \\ m_vasilenko@ukr.net
}

\begin{abstract}
Analysis of scientific literature and documental sources testifies to actualization of problem of professional preparation of the future fitness trainers at educational level "bachelor" in different countries. The special features of professional education of these specialists in Great Britain and Australia were determined. To the advantages of preparation can be assigned the flexible character of stage education and possibility to work as a fitness-trainer, having the second, third, fourth and fifth levels according to Qualification Credit Framework - QCF. The sixth level is equal to educational level "bachelor". Educational institution that realizes preparation at sixth level on specialization «Personal Fitness Training» is University of Central Lancashire. The content of university curriculum provides mastering by students of competences on psychology of communication, motivation, leadership, nutritiology, management, medical rehabilitation and so on. From our point of view, disadvantage of professional preparation of the future fitness-trainers in Great Britain and Australia is the excessive applied orientation of teaching and absence of cultural disciplines.
\end{abstract}

Keywords: fitness trainer, bachelor, educational establishment, vocational training higher.

\section{Introduction}

At the modern stage of development of Ukrainian society take place the dynamic processes of appearance of new professions, decrease of need for other ones, standartization of requirements to the professional preparation of future specialists according to Association Agreements between Ukraine and European Union. Such transformation takes place also in branch "physical education and sport". If previously the traditional professions for this sphere were "trainer of certain kind of sport" and "teacher of physical training", for today this branch is presented with series of specialties. Such situation needs distinct distribution of competences within each of them.

Since 2010 in higher educational institutions of Ukraine was started preparation of specialists of the "new" profession "fitness trainer". According to the studies of Recruitment \& Employment Confederation - REC, profession "fitness trainer" is in rating of first twenty professions that are in significant demand [1]. At that the lack of qualified staff is urgent.

In this connection appears an urgent problem of elaboration and improvement of correspondent educational programs. For building of effective system of professional preparation of the future fitness trainers in higher educational institutions we find it necessary to take into account the world experience, paying attention to positive achievements and negative consequences.

\section{Analysis of published data and problem statement}

In native and foreign scientific publications is actively discussed the necessity to review the content of preparation of specialists for the sphere of health-improving fitness, accented the actualization of professional preparation of fitness specialists in higher educational institutions under conditions of the new educational standards [2]. According to O. G. Saykina's studies, for the last 4 years in Russian fitness-industry was involved the significant number of graduates from higher educational institutions of physical training specialization (more than half of all graduates). It is caused by prestige of profession and high salary. Author indicates contradictions that appeared in Russia between existent social demand for the solution of problem of making population healthier and absence of unite system of preparation of fitness specialists 
in higher educational institutions. At the same time author pays attention to orientation of the modern young specialists on the narrow "Americanized" aspect of commercial success, at which spiritual, ethical components of preparation are ignored [3].

In literature is hold a discussion as to the necessity of explanation of new definitions in the sphere of fitness and pedagogy of professional education [4], grounding of fitness trainer's professional competences [5]. In previous publications we considered the experience of USA, Baltic countries, Germany and Russia and noted the world tendency to rise of employers' requirements to the level of education of the future fitness trainers, especially the level not lower than "bachelor" is needed. Along with that, it is accented, that in developed countries the significant part in professional preparation of the future fitness trainers is occupied by non-university sector of education (at educational level junior specialist) [6-9].

It must be noted, that the question of features of professional preparation of the future fitness in Great Britain and Australia is insufficiently studied. From our point of view, the great popularity and old traditions of development of health-improving fitness in these countries make expedient to study the structure and content of professional educational programs and to analyze the ways of integration of education of the future fitness trainers in Ukrainian system of higher education.

\section{Purpose and objectives of the research}

The purpose of our research is to analyze advantages and disadvantages of professional preparation of the future fitness trainers in Great Britain and Australia.

The tasks of research are following:

1. To determine the features of stage education of the future fitness trainers in Great Britain and Australia.

2. To analyze the structure and content of curriculums of preparation of the future fitness trainers in Great Britain and Australia at "bachelor" educational level.

3. To determine the disadvantages of professional preparation of the future fitness trainers in Great Britain and Australia.

\section{Materials and methods of research}

For realization of research were used the method of system analysis; analysis and generalization of scientific-methodological literature, content-analysis of documental materials, method of comparison and correlation.

\section{Results of the research and discussion of the results}

As it is provided by Qualification Credit Framework - QCF, 2 types of professional higher education are separated: the higher professional technical education or «further education» and the higher academic one. According to legislation of this country, all professional qualifications are classified by 8 levels that include the levels of study at secondary school, further study at professional-technical and higher school. The first level of education is characterized with study at school and getting of general secondary education certificate. At the second level of education, after correspondent learning can be get certificate on primary professional education. The third level of qualification is provided by the study at professional-technical schools, colleges, universities and is finished with getting qualification or Certificate of specialist. The fourth level is finished with getting Higher National Diploma-HND, and fifth one - with getting Higher National Certificate - HNC. This diploma includes 240 credits according to the system of Great Britain and 120 ones according to European one. The sixth level is characterized with getting bachelor degree. The seventh level is finished with getting master degree, and the eighth level - PhD [10].

From today positions Great Britain has The Register of Exercise Professionals - REPS that regulates the market of services of professional fitness trainers, provides correspondence to the national standards and code of professional ethics, realizes legal protection of specialist 
and population. According to the proposition of Register, study of the future fitness trainer on courses and getting certificate (diploma) on the different fitness specializations corresponds to the second, third and fourth levels of qualification. After finish of the study there is a possibility to get the following documents: Certificate in Activity Leadership, Level 2; Diploma in Instructing Exercise and Fitness, Level 2; Certificate in Customer Service, Level 2; Diploma in Sport and Active Leisure, Level 2; Certified Personal Trainer, Level 3; Diploma of Personal Trainer, Level 4.

The fourth level of fitness trainer's qualification conditions getting certificate or diploma of correspondent academic degree that allows work with special categories of population [11].

According to requirements of Britain legislation, for confirmation of classification specialists (not depending on education level) must undergo training on courses for getting license for the right to practice profession. Students have a possibility to master such fitness specialties as: "Gymnastics instructor", "Aqua trainer", "Instructor of group activities at musical accompaniment", "Personal trainer", "Yoga trainer", "Pilates instructor", "Instructor in exercises", "instructor for work with special categories of population", "Dances teacher" and so on [12].

In Great Britain are the following private organizations that have right to realize teaching and certification of fitness trainers from the second to fourth level according to the National qualification frame: Active IQ, Central YMCA Qualifications (CYQ), City And Guilds [13].

The famous institution of professional education in Great Britain is Premier Training International that has branches in 40 cities of the country. Center offers to master programs, duration of each of them is $8-10$ weeks. Students study on both stationary and distant form of education, pass exams and are supplied with learning literature and video-materials.

The study in Premier Training International gives a possibility to get the following document on education: Certificate in Fitness Instructing, Level 2; Certificate in Teaching Exercise and Fitness, Level 2; Diploma in Fitness Instructing, Level 2; Diploma in Fitness Instructing and Personal Training, Level 3; Certificate in Personal Training, Level 3; Diploma in Exercise Referral, Level 3; Certificate in Physical Activity and Lifestyle Strategies for Managing Low Back Pain, Level 4; Diploma in Specialist Exercise/Low Back Pain, Level 4; Diploma in Specialist Exercise/Obesity and Diabetes, Level 4) [14].

Educational institution that realizes professional preparation of specialists for fitness sphere at the levels 4 and 5 is Cambridge Regional College, to enter in it, it is necessary ho have certificates of third level of fitness specialization. After finishing college graduates get document on high education - Diploma in Sport on the specialty "Coaching \& Sports Development". Duration of the study is one year. Curriculum of this program provides learning of the following disciplines: "Sport and Exercise Psychology"; "Field-based Fitness Testing for Sport and Exercise"; "Applied Sports Coaching"; "The Sport and Leisure Industry"; "Work-based Experience"; "Sport and Exercise Massage"; "Principles of Sports Coaching" [15].

In The University of Central Lancashire in Preston is realized preparation of bachelors on specialization "Personal fitness training". This University is one of the most outstanding Universities of Great Britain and World. In its structural subsection, The School of Sport and Wellbeing, several qualifications can be acquired. Among them: Bachelor of Science, Nutrition and Exercise Sciences (Personal Fitness Training)) and Bachelor of Science, Nutrition and Exercise Sciences (Human Nutrition)). Along with it there is a possibility to finish MA program and get degree of Sport and Exercise Science, Master of Science; Sport and Exercise Biomechanics, Master of Science).

Within the first year of preparation of Bachelor of Science, Nutrition and Exercise Sciences (Personal Fitness Training) the study of following disciplines is provided; Introduction to Applied Human Physiology (XS1200); Introduction to Biology (XS1202); Introduction to Nutrition (XS1600); Introduction to Research Methods (XS1700); Health and The Social Sciences (HS1100); Introduction to Exercise Leadership \& Gym Orientation (XS1106); Health Fitness and Performance (XS1500); Language (option) (AL****). In the first year of study student must get 120 credits that is equivalent of Certificate of Higher Education in Nutrition and Exercise Sciences. 
In the second year of education students have a possibility to study the following disciplines: Physiology of Human Performance (XS2200); Nutrition for Life (XS2600); Research Methods (PS2710); Health \& Fitness (TL2130); Essentials of Sports Training and Conditioning (option) (XS2500); Sport Nutrition (option) (XS2601); Experiential Learning (option) (TL2066); Language (option) AL****. The second year of study also provides 120 credits.

Students of the third year master knowledge of the following disciplines: Research Project (XS3900); Advances in Fitness Training (TL3153); Exercise Referral (XS3200); Consultancy Project (TL3104); Current Topics in Population Health and Exercise (option) (XS3203); Advanced Methods in Performance Assessment and Conditioning (option) (XS3204); Nutrition and Health (XS3601); The Psychology of Diet and Exercise (option) (PS3035). Totally, in three year student must get at least 360 credits and reach the bachelor degree in "Nutrition Sciences and Physical exercises" (specialty "Personal fitness training") [16].

Preparation of staff of sport, physical education and health protection fields is realized also by the other higher academic educational institutions. Thus, Kingston University London, London Metropolitan University, and Anglia Ruskin University train Bachelor of Science, Sport Science).

In The University of Exeter one can get the degree of Bachelor of Science, Exercise and Sport Sciences.

Southampton Solent University offer students to get the degree of Bachelor of Arts, Sport and Physical Education and Bachelor of Science, Applied Sport Science. Duration of education in all higher educational institutions is 3 years.

Our analysis of curriculums of aforesaid universities allows state that only in Southampton Solent University in the second year of education further specialists study such disciplines, necessary for work in fitness and training sphere, as: "Application of Fitness Testing and Training" and "Health, Fitness and Programme Design») [17].

Let's consider the specificity of professional preparation of fitness trainers in Australia.

According to the data of Industry Research Division - IBISWorld of Australia, the profession "fitness trainer" is rather popular and highly paid. It is accented, that every year the demand for study on fitness professional direction raises approximately by 4,8 \% [18].

The system of professional training of future fitness trainers, from our point of view, has common features with educational system of Great Britain but there are also differences. According to Australian Qualifications Framework, after finish of the primary stage of professional-technical qualification students get Certificates that are divided in 4 levels (I - lowest, IV - highest). Certificate of the professional direction "fitness" can be gotten after study in institutions of the state system of professional education, in private higher educational institutions, colleges and universities. The terms of study are from 6 month to 1,5 years.

At the next level of professional qualification students get Diploma and Diploma Advanced. The term of study on diploma programs is $2-3$ years. Diploma gives student a possibility to enter in University directly on 2-3 year. On condition of successful finish of the university graduate gets full higher education [19].

Fitness trainers must be registered in professional associations, especially "Fitness Australia" or "Physical Activity Australia". For confirmation of membership each fitness trainer must pass the programs of qualification improvement every 2 years. In the Table $\mathbf{1}$ is given the list of organizations that realizes preparation of fitness training in Australia.

The one of accredited training centers that gives a possibility to get certificates of III, IV levels and Diploma Personal Trainer is International Career Institute - ICI that has independent representatives in different countries, especially, New Zealand, Great Britain, Ireland, USA and Canada. Study is realized during 8-9 months in distant and stationary forms. Students are offered to learn the following disciplines: «Exercise Physiology»; «Exercise Principles»; «Human Biomechanics»; «Risk Assessment»; «Aqua fitness»; «Aqua fitness, exercise, routines, and equipment»; «Fitness Program Design»; «Delivering A Fitness Program»; «Ergogenic Aids to Performance»; «Safety \& Injury»; «Nutrition»; « Fitness Programs for Special 
Groups»; «Principles of Fitness»; «Human Anatomy»; «Exercise Science»; «Client Communication»; «Motivation»; «Fitness Programming». At the same time International Career Institute after correspondent training gives a possibility to get Diploma of Fitness and Diploma advanced that corresponds to the level of primary higher education [20].

Sutherland College is referred to Sydney TAFE. The list of competences that must be mastered by students includes: SFFIT421A: planning and realization of staff training; SISFFIT416A: use of methods of motivational psychology; SISFFIT415A: work together with medical and adjacent specialists of health protection system; SISFFIT417A: making of training activity plan; SISFFIT314A: planning and realization of activities with elderly clients; SISFFIT313A: planning and realization of activities for healthy children and teens; SISFFIT418A: assessment of physical training; SISFFIT420A: planning and realization of activities for correction of overweight; SISFFIT419A: use of scientific principles of motional activity in practice; BSBSMB401A: organization of small business in fitness; SISSSTC402A: elaboration of programs of force and conditioned training; SISFFIT312A: planning and realization of activities on aerobic training; CHCIC301E: work with child contingent; SFFIT421A: planning of arrangements for the work with staff [21].

Table 1

The list of organizations that realizes preparation of fitness training in Australia

\begin{tabular}{|c|c|c|c|}
\hline Name of institution & Level of education & Form of study & Term of study \\
\hline International Career Institute & $\begin{array}{l}\text { Certificate III in Fitness, Certificate IV in Fitness } \\
\text { Diploma of Fitness end Diploma advanced }\end{array}$ & $\begin{array}{l}\text { Stationary, correspon- } \\
\text { dence, distant }\end{array}$ & 8-9 months \\
\hline Sutherland College & Certificate IV in Fitness & Correspondence, distant & 6 months \\
\hline Fitness Industry Training & Certificate IV in Fitness & $\begin{array}{l}\text { Stationary, correspon- } \\
\text { dence, distant }\end{array}$ & Unlimited \\
\hline $\begin{array}{l}\text { The Australian Institute of } \\
\text { Fitness }\end{array}$ & $\begin{array}{c}\text { Certificate III in Fitness, Certificate IV in Fitness } \\
\text { Diploma of Fitness }\end{array}$ & $\begin{array}{l}\text { Stationary, correspon- } \\
\text { dence, distant }\end{array}$ & Unlimited \\
\hline $\begin{array}{l}\text { The Canberra Institute of } \\
\text { Technology }\end{array}$ & $\begin{array}{c}\text { Certificate III in Fitness, Certificate IV in Fitness } \\
\text { Diploma of Fitness }\end{array}$ & $\begin{array}{l}\text { Stationary, correspon- } \\
\text { dence, distant }\end{array}$ & 1 semester \\
\hline $\begin{array}{l}\text { The Australian College of Sport } \\
\qquad \& \text { Fitness }\end{array}$ & $\begin{array}{c}\text { Certificate III in Fitness, Certificate IV in Fitness) } \\
\text { Diploma of Fitness }\end{array}$ & $\begin{array}{l}\text { Stationary, correspon- } \\
\text { dence, distant }\end{array}$ & Unlimited \\
\hline $\begin{array}{l}\text { Australian Correspondence } \\
\text { Schools Distance Education) }\end{array}$ & Diploma in Fitness science & Distant & $\begin{array}{l}\text { At least } 2500 \\
\text { hours }\end{array}$ \\
\hline Australian Fitness Academy & $\begin{array}{c}\text { Certificate III in Fitness, Certificate IV in Fitness } \\
\text { Diploma of Fitness }\end{array}$ & $\begin{array}{l}\text { Stationary, correspon- } \\
\text { dence, distant }\end{array}$ & Unlimited \\
\hline $\begin{array}{l}\text { The Australian College of } \\
\text { Physical Education }\end{array}$ & $\begin{array}{l}\text { Certificate III in Fitness, Certificate IV in Fitness } \\
\text { Bachelor of Applied Fitness }\end{array}$ & Stationary, distant & 3 years \\
\hline
\end{tabular}

In The Australian Institute of Fitness, The Canberra Institute of Technology and The Australian College of Sport \& Fitness are offered curriculums of analogous content but special attention is paid to the medical set of disciplines [22, 23].

From our point of view, the special attention must be paid to the activity of Australian Correspondence Schools Distance Education that has old traditions of staff training in the different branches of industry. It is specific, that in this institution is systematically used the prob- 
lem approach to study and are elaborated the correspondent algorithms of work. Students, who chose the specialty "Fitness" must master knowledge and skills in volume 2500 hours, among them 800 hours are devoted to obligatory module, 600 hours - to elective courses 200 hours are allotted for scientific researches on certain problems (realization of three projects is provided), 200 are devoted to the study of optional disciplines, 600 hours - to confirmation of practical skills, 100 hours - to participation in branch seminars, conferences, fitness-forums and so on. Obligatory course of study includes the following modules: BRE101 «Health \& Fitness»; BSC101 «Human Anatomy \& Physiology»: «Human Biology I»; BSC103 «Biochemistry I Animal and Human»; BBS101 «Business Studies»; BRE102 «Human Nutrition»; BGN101 «Instructional Skills»; BRE103 «Leisure Management I»; BRE103 «Leisure Management II»; BGN102 «Research Project»; VBS103 «Workplace Health \& Safety»; BGN103 «Workshop»; BRE204 «Leisure Facility Management 2»; BRE205 «Leisure Management III»; BRE205 «Leisure Management IV»; BIP001 «Industry Project II».

Optional modules are the following: BPS106 «Sports Psychology»; BRE208 «Advanced Aerobics»; BRE207 «Aquafitness»; BRE201 «Health \& Fitness II»; BSS200 «Healthy Buildings»; BRE202 «Human Nutrition II»; BRE210 «Nutrition for Weight Loss»; BRE206 «Resistance \& Gym Supervision»; BGN203 «Workshop II»; BSC301 «Cardiorespiratory Performance»; BRE301 «Health \& Fitness III»; BRE302 «Human Nutrition III»; BPS305 «Life Coaching»; BRE303 «Sports Nutrition»; BRE307 «Weight Loss Consultant» [24].

Analysis of content of aforesaid modules testifies that significant attention is paid to the mastering by future fitness trainers of knowledge on rational, medical nutrition and methodical aspects of training persons with overweight.

The feature of study in Australian Fitness Academy is that in complex with "traditional" disciplines is offered a module, directed on the study of "Musculoskeletal Injury Prevention and Management"; Health Management Strategies \& Chronic Disease Prevention"; "Exercise Guidelines for Neurological Conditions \& Disability» and "Exercise Guidelines for Children with Chronic Conditions»[25].

In Australia single educational institution that realizes professional preparation of fitness trainers of academic degree Bachelor Health Science \& Fitness Training is The Australian College of Physical Education. The learning program of this college is elaborated at participation of FPA. The program includes 3 years that is 6 semesters of 12 weeks (Table 2).

To the advantages of Bachelor Health Science \& Fitness Training can be assigned: academic higher education; possibility to work as a professional trainer just after second year of study; ability to occupy the following posts after finishing college: "Rehabilitation Consultant», "High Performance Coach or Manager», «Health or Fitness Researcher», «Fitness Leaders for specific demographics/cardiac rehabilitation, exercises for the elderly» and «Personal Trainer».

Along with it after finishing college students have a possibility to get the following degrees: Bachelor Science of «Strength \& Conditioning Training», Bachelor Science of «Exercise Physiology», Bachelor Science of «Sports Science», Bachelor Science of «High Performance Sport» and (Bachelor Science of «Education»).

It must be noted, that the system of professional preparation of fitness trainer in Australia is rather democratic. Person, who has basic secondary education or special professional education; special or adjacent higher academic education can work as fitness trainer. There are universities, where the training in branches of science, adjacent to fitness, is realized. Thus, The University of South Australia offers to get degree of Bachelor of Applied Science «Human Movement and Health Studies» [26]. In La Trob University and The Deakon of University training of Bachelor of Physical and Health Education is realized [27]. In The University of Sydney is possible to get Bachelor of Applied Science «Exercise and Sport Science». According to recommendations of The National Association of Career Colleges, person, who has non-specialized academic higher education and want to work as fitness trainer, must take course of specialization in fitness and in further confirm its membership by the regular certification [28]. 
Table 2

Fragment of curriculum of The Australian College of Physical Education Bachelor Health Science \& Fitness Training

\begin{tabular}{|c|c|}
\hline Code & Name of discipline \\
\hline \multicolumn{2}{|r|}{ I year of study } \\
\hline GHS1301U & Understanding Health \\
\hline HSC1102 & Chemistry \\
\hline HSC1101 & Biology \\
\hline PER1102 & (Fitness Principles and Programming \\
\hline HSC1202 & Musculo-Skeletal Anatomy and Physiology \\
\hline HSC1201 & Application of Maths and Statistics for Health and Sport \\
\hline HSC1203 & Biochemistry and Nutrition \\
\hline PER1203 & Methods of Motivation in Fitness \\
\hline \multicolumn{2}{|r|}{ II year of study } \\
\hline HSC1256 & Applied Exercise Physiology \\
\hline HSC2305 & Systems Anatomy \& Physiology \\
\hline PER2105 & Strength and Conditioning \\
\hline PER1204 & IT in Fitness \\
\hline PER1104 & Introduction to Responsible Fitness Management \\
\hline GHS2202 & Principles of Health Promotion \\
\hline HSC2201 & Biomechanics \\
\hline HSC1204 & Exercise Prescription Throughout The Lifespan \\
\hline PER2104 & Introduction to Understanding Sport \& Fitness Research \\
\hline \multicolumn{2}{|r|}{ III year of study } \\
\hline GHS3803 & Research Design and Epidemiology \\
\hline HSC3203 S & Human Pathophysiology and Pharmacology \\
\hline HSC3102 & Mechanics of Prevention \& Rehabilitation \\
\hline PER3112 & Professional Integrity \\
\hline PER2374 & Psychology \\
\hline GHS3256 & Health and Physical Assessment \\
\hline PER1207 & Exercise \& Social Development through the Lifespan \\
\hline HSC3202 & Health, Lifestyle Disease and Exercise Prescription \\
\hline
\end{tabular}

\section{Conclusions}

Thus, an analysis of informational resources allowed us create integral picture of specificity of professional preparation in the higher educational institutions of Great Britain and Australia. Generalizing the aforesaid, the following conclusions can be made.

1. The advantage of stage system of education in Great Britain is its variation character (as opposite to Ukrainian one). The profession "fitness trainer" can be acquired at the different levels of education: from second to fifth. The forth level it is a level of specialist that is finished with getting Specialist Diploma or Higher National Certificate. Getting such document is approximately equal to the one year of university education and is qualified higher that the Specialist Diploma, but lower than Higher National Diploma. The study of Australian experience of preparation of fitness trainers demonstrated that the system of professional training has common features with the one of Great Britain but there are also differences. We can assign to them the more flexible system of certification of fitness trainers and requirements to the regular certification of specialists.

2. As opposite to Ukraine (where near 10 higher educational institutions prepare the future fitness trainers at the lever "bachelor") in Great Britain such specialized training is realized in The University of Central Lancashirein Preston. It is important, that teaching programs are elaborated with participation of professional fitness associations. It is worth paying attention, that the content of university curriculum includes disciplines from the cycle of dietetics, medical rehabilitation, pathophysiology, psychology of communication and leadership. Such disciplines must be widely introduced into native practice. It is established, that programs of higher education at educational level "bachelor" are not spread in Australia. The single edu- 
cational institution of Australia that realizes preparation of Bachelor Health Science \& Fitness Training is The Australian College of Physical Education. At that fundamental character of the learning program content is worth paying attention.

3. From our point of view, disadvantage of professional preparation of future fitness trainers in Great Britain and Australia is excessive applied orientation of study and lack of cultural disciplines.

\section{Acknowledgements}

Author finds it necessary to note Ukrainian scientists, which work and personal contacts favored the formation of scientific interest in selected subject field: M. Dutchak, L. Slushenko, E. Andreeva. V. Levitsky and officials of department of health, fitness and recreation of the National University of Physical Education and Sport of Ukraine and expresses gratitude to them.

\section{References}

[1] Recruitment and Employment Confederation. Available at: https://www.rec.uk.com

[2] Malek, M. N., Nalbon, D. P., Berger, D. E., Coburn, J. W. (2002). Importance of health science education for personal fitness trainers. Journal of Strength and Conditioning Research, 16 (1), 19-24.

[3] Saykina, E. G., Smirnova Yu.V. (2015). Aktualizatsiya professionalnoy podgotovki spetsialistov po fitnesu v vyisshih uchebnyih zavedeniyah v usloviyah novyih obrazovatelnyih standartov. Sovremennye problemy nauki i obrazovanija, 3. Available at: http://science-education.ru/ru/article/view?id=17499

[4] Saykina, E. G. (2011). Semanticheskie aspektyi otdelnyih ponyatiy v oblasti fitnesa. Teorija i praktika fizicheskoj kul'tury, 8, 6-10.

[5] Dutchak, M. V., Vasy'lenko, M. M. (2013). Teorety'chne obgruntuvannya kvalifikacijnoyi xaraktery`sty`ky` fitnes-trenera. Pedagogika, psihologija i mediko-biologicheskie problemy fizicheskogo vospitanija i sporta, 2, 17-21. doi:10.6084/m9.figshare.639254

[6] Vasilenko, M. M. (2012). Suchasny`j stan ta problemy` pidgotovky` fitnes-treneriv v SShA. Pedagogika, psihologija i mediko-biologicheskie problemy fizicheskogo vospitanija i sporta, 11, 19-22.

[7] Vasilenko, M. M. (2012). Specy’fika pidgotovky` majbutnix fitnes-treneriv v Nimechchy'ni ta Avstriyi (v porivnyal 'nomu aspekti). Pedahohika formuvannya tvorchoyi osobystosti u vyshchiy i zahal'noosvitniy shkolakh, 26 (79), 126-130.

[8] Vasilenko, M. M. (2013). Dosvid pidgotovky` treneriv z fitnesu v krayinah Baltiyi. Bulletin of the Chernihiv National Pedagogical University, 107, 1, 85-89.

[9] Vasilenko, M. M. (2013). Tendenciyi rozvy'tku sy’stemy` osvity` majbutnix fitnes-treneriv u Rosijs'kij federaciyi. Scientific journal National Pedagogical Dragomanov University, 4 (29), 166-170.

[10] Qualifications and credit framework: requirements. Available at: www.gov.uk/government/collections/qualifications-and-credit-framework-requirements

[11] Register of Exercise Professionals. Available at: www.exerciseregister.org

[12] Continual Professional Development. Available at: https://www.cipd.co.uk/cpd

[13] Active IQ. Available at: http://activeiq.co.uk/qualifications

[14] Premier Training International. Available at: http://www.premierglobal.co.uk/home

[15] Cambridge Regional College. Available at: http://www.camre.ac.uk

[16] University of Central Lancashire. Available at: http://www.uclan.ac.uk/courses/bsc_hons_nutrition_exercise_sciences_personal_fitness_training.php

[17] Kingston University London. Available at: http://www.kingston.ac.uk/undergraduate-course/ sport-science

[18] Industry Research Division. Available at: http://www.ibisworld.com default.aspx

[19] Australian Correspondence Schools Distance Education. Available at: http://www.acs.edu.au/

[20] International career Institute. Available at: http://ici.edu.au

[21] Sutherland College. Available at: https://www.tafensw.edu.au

[22] Australian Institute of Fitness. Available at: http://fitness.edu.au

[23] Canberra Institute of Technology. Available at: http://cit.edu.au/ default.aspx

[24] Australian Correspondence Schools Distance Education. Available at: http://www.acs.edu.au/

[25] Australian Fitness Academy. Available at: http://afa-elearning.mywisenet.com.au

[26] University of South Australia. Available at: https://www.unisa.edu.au/Study/rehabilitation-health-sport

[27] Deakon of University. Available at : www.deakin.edu.au

[28] National Association of Career Colleges (NACC)). Available at: http://nacc.ca/ 